\title{
Beyond Leveraged Losses: The Balance Sheet Effects of the Home Price Downturn
}

\begin{abstract}
This paper quantifies the impact of declining home prices, increasing mortgage credit losses, and the associated reduction in credit supply on real GDP growth. Using a state-level panel analysis, I first estimate the link between home prices and foreclosures. I estimate that an additional 15 percent home price decline from mid-2008 levels would be consistent with total residential mortgage credit losses over 2007-12 of $\$ 750$ billion, although the uncertainty is high. I then gauge the impact of such losses on the supply of credit from banks, asset-backed security markets, and the governmentsponsored enterprises, and in turn on real GDP growth. In the central scenario, the crisis could lower real GDP growth in 2008 and 2009 by an average of 2.6 percentage points per year. This estimate excludes both adverse multiplier effects (labor market deterioration, global trade repercussions, and credit quality feedback) and policy offsets.
\end{abstract}

\footnotetext{
he current housing market downturn weighs on the economy in four main ways. First, the sharp decline in residential construction activity reduces aggregate output directly. From the fourth quarter of 2005 to the third quarter of 2008, declining real residential investment subtracted a cumulative total of 2.5 percentage points from real GDP growth.

Second, declining income in the housing sector in turn has effects on other parts of the economy. Laid-off construction workers and real estate agents cut back on consumer spending, homebuilders (and their subcontractors) invest less in construction equipment, and nonresidential construction firms see less demand for new commercial development. These second-round effects are harder to quantify because they are so spread out through the economy, but they are likely to be significant as well.
} 
Third, declining home prices weigh on aggregate personal consumption through either a negative wealth effect or a mortgage liquidity effect, or both. Households who spent more than they earned during the boom by borrowing against the rising value of their home may be forced to cut back. Even households who did not outspend their income might reduce their consumption in response to a decline in their wealth or their permanent income, or both. Most studies analyzing this issue find evidence for a housing wealth effect, but its size varies widely depending on the time period and the empirical design. ${ }^{1}$

Fourth, losses on mortgage credit deplete the equity capital of leveraged financial institutions and persuade them to reduce their financial leverage. This reduces the supply of credit to households and nonfinancial businesses. David Greenlaw, Hatzius, Anil Kashyap, and Hyun Song Shin (henceforth GHKS) find that an assumed $\$ 500$ billion in aggregate mortgage credit losses could cut real GDP growth by 1.5 percentage points over a year's time. ${ }^{2}$

This paper focuses on the fourth channel. Building on the study by GHKS, its main contributions are a more detailed empirical analysis of the link between home price declines and mortgage credit losses and a more systematic look at the role of the asset-backed security (ABS) markets. The first section analyzes the links between home prices and foreclosures, and ultimately between home prices and mortgage credit losses, using a state-level panel dataset for the period 1998-2008 to predict foreclosures. The second section discusses the impact of mortgage credit losses on the supply of credit to private nonfinancial borrowers, with a particular focus on on-balance-sheet lending by banks and other leveraged financial institutions, off-balance-sheet lending through the ABS markets, and lending backed by government-sponsored enterprises (GSEs) such as Fannie Mae and Freddie Mac. The third section discusses the potential impact on economic activity, using an instrumental variables approach to estimate the link between credit supply and real GDP growth. The fourth section concludes.

\section{The Link between Home Prices and Credit Losses}

The underlying cause of the recent financial crisis is the decline in home prices and the associated increase in foreclosures and credit losses. Fig-

1. For an overview, see Muellbauer (2007).

2. Greenlaw and others (2008). 
Figure 1. Two Measures of the Decline in Home Prices, 1992-2008

Percent change from one year before

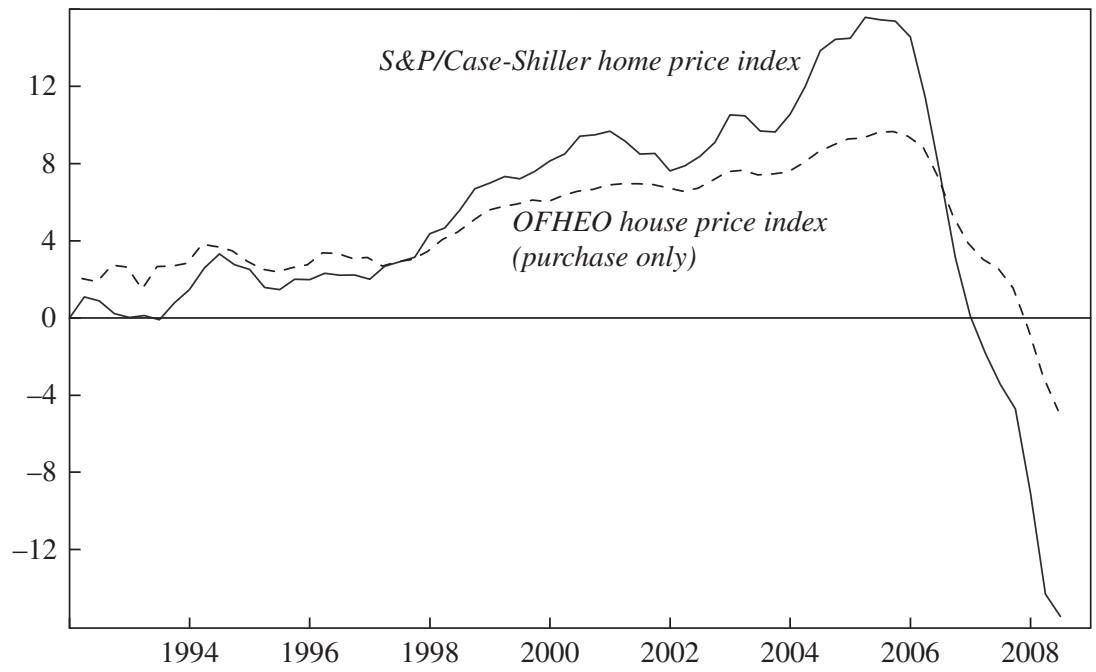

Sources: Office of Federal Housing Enterprise Oversight, Standard \& Poor's, Fiserv, and MacroMarkets.

ure 1 shows the current pace of decline in home prices as measured by the two most widely used measures, the S\&P/Case-Shiller U.S. National Index and the purchase-only OFHEO index, seasonally adjusted, constructed by the Office of Federal Housing Enterprise Oversight. As of the second quarter of 2008, home prices on a year-on-year basis were down 15.4 percent according to the Case-Shiller index and 4.8 percent according to the OFHEO index. ${ }^{3}$

3. The large difference between the two indexes is due to three main factors. First, the Case-Shiller index is weighted by market capitalization, whereas the OFHEO index is weighted by the number of households. This means that the Case-Shiller index gives more weight to regions with high average home values, in particular the coasts, which generally have seen larger home price swings. Second, the Case-Shiller index includes all home transactions, whereas the OFHEO index includes only transactions involving conforming mortgages. This means that the OFHEO index has missed the direct effects of the subprime mortgage boom and likely understates the rate of home price decline in the broad housing market. Third, the Case-Shiller index covers only 70 percent of the United States (by market value), whereas the OFHEO index has near-complete geographic coverage. Since the regions excluded by the Case-Shiller index are generally rural and relatively stable, the Case-Shiller index likely overstates the rate of home price decline in the broad housing market. 


\section{Existing Approaches to Measuring Mortgage Credit Losses}

The key question this section of the paper asks is how large an aggregate mortgage credit loss will result from the decline in home prices. Analysts have attempted to answer this question in three main ways. First, some have estimated "market-implied" losses from indexes such as the ABX.HE index of prices of subprime credit derivatives. ${ }^{4}$ But although such an estimate of market-implied losses is useful for gauging how much principal financial institutions that mark to market will need to write down in the near term, there is no particular reason to think that it will prove to be an accurate gauge of ultimate credit losses. Indeed, if analysts were to use market prices to forecast credit losses, and the market then relied on these forecasts to price assets, the cat would be chasing its own tail.

Second, many applied mortgage credit analysts use detailed vintage-byvintage data to estimate credit losses by projecting forward historical delinquency, default, and loss curves. Here the key assumption is that although different mortgage vintages (a vintage is the set of mortgages initiated in a given year) have different default trajectories, the relative progression through time is stable, or at least highly predictable. For example, suppose that the cumulative default rate of the 2006 subprime vintage is 3 percent at the end of 2007. Suppose further that the 2004 vintage showed a cumulative default rate of 1 percent after one year and 4 percent after three years, for a fourfold increase over two years. In that case the model implies that the 2006 vintage should show a 12 percent default rate by 2009. The problem with this approach should be readily apparent, namely, that within-vintage patterns are unlikely to remain stable as one goes from a rising to a falling home price environment. At a minimum, one should adjust the curves for falling home prices, but this is difficult to do because the detailed data required for building these vintage-by-vintage models are available only back to the late 1990s, a period without a national housing downturn until very recently.

Third, one can use historical relationships among defaults, home prices, and perhaps other economic variables to estimate future default rates. For example, Adrian Blundell-Wignall estimates an equation that explains the subprime delinquency rate by GDP, home prices, and unemployment, using data from 1998 to $2007 .{ }^{5}$ He then uses the resulting equation, along with assumptions about the relationships among delinquencies, defaults,

4. For example, Blundell-Wignall (2008), GHKS (2008), and Bank of England (2008).

5. Blundell-Wignall (2008). 
and losses and trends in the explanatory variables, to forecast credit losses. The problem with this approach is that the underlying dataset is confined to 40 aggregate observations during a period that, again, saw no housing downturn except at the very end.

\section{A State-Level Approach}

Given these limitations, it is more promising to use disaggregated region-by-region information that includes at least some periods of declining home prices in each region to estimate the relationship between home prices and mortgage credit performance. For example, GHKS look at foreclosure data from the Texas, California, and Massachusetts housing downturns of the 1980s and 1990s to gauge what a significant nominal home price downturn could mean for foreclosures. Nominal home price declines in these episodes of 10 to 15 percent resulted in a tripling of the rate of foreclosure starts over a two-to-six-year period, with only a gradual decline thereafter. Extrapolating this observation to the post-2007 national housing market, and making assumptions about the percentage of foreclosure starts that result in repossessions and about average "severity" (the size of the loss associated with a default), GHKS argue that the regional precedents may be consistent with total losses of around $\$ 500$ billion in the current episode.

However, this region-by-region approach is also subject to several limitations. One could argue, on the one hand, that it is too pessimistic, because the rise in foreclosures in the three regional downturns was undoubtedly partly due to the massive labor market deterioration recorded in all three cases. From the start of the downturn, the unemployment rate rose by a cumulative 3.3 percentage points in Texas, 4.8 percentage points in California, and as much as 6.0 percentage points in Massachusetts. For comparison, the biggest national increase in the postwar period totaled 4.4 percentage points, seen in the 1973-75 recession. Although the national labor market is clearly deteriorating quite sharply at present, using such a large decline as the baseline assumption may be too extreme.

On the other hand, one could argue that the region-by-region approach delivers overly optimistic results, because it cannot take account of the farreaching structural changes in the housing and mortgage markets that have occurred since these regional episodes. In particular, the subprime mortgage market barely existed before the mid-1990s. Since a large share of the current problem is concentrated in the subprime market, this might suggest that the current downturn may be more severe. The behavior of mortgage borrowers may also have changed. As recently as the early 1990s, it seems 
that only a relatively small share of homeowners with negative equity ended up defaulting on their mortgage debt. For example, Christopher Foote, Kristopher Gerardi, and Paul Willen show that only 6.4 percent of Massachusetts homeowners who were estimated to be in negative equity at the end of 1991 defaulted over the next three years. ${ }^{6}$ Now, however, anecdotal reports, at least, suggest that a significant number of borrowers walk away from their mortgage once they are in negative equity. This could imply that the impact of home price declines on defaults will be larger in the current national episode than in the three regional downturns.

The model presented in this paper instead uses more recent state-level information to estimate the link between home prices and foreclosures, and ultimately between home prices and credit losses. I use quarterly panel data from the Mortgage Bankers Association (MBA) for all 50 states and the District of Columbia over the period 1998Q1-2008Q2 to estimate the relationship between the logarithm of the state foreclosure rate and changes in nominal state home prices as measured by the purchase-only OFHEO index. ${ }^{7}$ I estimate separate equations for prime adjustable-rate, prime fixed-rate, subprime adjustable-rate, and subprime fixed-rate loans and include state and time fixed effects as well as three lags of the dependent variable. ${ }^{8}$

I then use these equations to project state-level foreclosure rates for each type of mortgage for a given home price path and combine these projections with assumptions about the estimated foreclosure completion rate and mortgage loss severity to calculate a path for total mortgage credit losses. Finally, by summing up these period-by-period losses over 2007-12, I obtain a rough estimate of total credit losses on the currently outstanding stock of residential mortgage debt.

This approach has some important advantages compared with previous analyses. First, when combined with assumptions about foreclosure completions and severities, it allows the implications for foreclosures of a given change in the home price outlook to be estimated using a very simple and transparent method. Other approaches, including the regional approach of GHKS, do not allow such a calculation.

6. Foote, Gerardi, and Willen (2008b).

7. Unfortunately, the Case-Shiller home price index is not available at the state level. The purchase-only OFHEO index is generally viewed as the most reliable state-level home price measure.

8. It is well known that a simple fixed effects estimator leads to downwardly biased coefficient estimates on the lagged dependent variable. However, the results in Judson and Owen (1997) suggest that the bias should be very small given the dimensions of the panel, which covers all 50 states and the District of Columbia and 42 periods. 
Second, this approach brings a large amount of state-by-state information to bear on the problem. Depending on the specification, almost 2,000 observations are available on the link between changes in home prices and foreclosures at the state level. This is especially noteworthy because the panel structure of the dataset ensures that the large sample does not include old data from periods when the behavior of borrowers and lenders may have been very different, such as the early-1990s downturn.

Third, this approach models foreclosures for different types of mortgages and can therefore take into account potential differences in the performance of subprime versus prime mortgages, and adjustable-rate (ARM) versus fixed-rate (FRM) mortgages. ${ }^{9}$ Subprime borrowers are more vulnerable to default than prime borrowers, both because they tend to be financially weaker and because they have, in recent years, often taken out mortgages with higher loan-to-value ratios in particularly "frothy" parts of the country.

This analysis also has some clear limitations. First, and most important, it extrapolates a fairly recent event- the unprecedented downturn in mortgage credit quality that started in late 2006 or early 2007-into uncharted territory. Despite the large number of observations, it would be optimistic to believe that the analysis will reveal stable (let alone "structural") relationships between home prices and foreclosures. At best one can hope to provide an order-of-magnitude estimate of the likely amount of mortgage credit losses assuming a particular outcome for home prices.

Second, because the analysis is reduced-form in nature, one cannot be sure about the causal relationship between home prices and foreclosures. Although Foote and his coauthors argue persuasively that home prices have a bigger impact on foreclosures than foreclosures have on home prices, the arrows of causation surely run in both directions. ${ }^{10} \mathrm{~A}$ good instrument for state-level home prices that might settle this issue is unavailable. However, this does not appear to be a serious problem, because much of the interest in the link between home prices and mortgage credit losses is of a "reduced-form" variety. That is, one would like to know what mortgage

9. The distinction between prime and subprime is not entirely clean. Participants who service both prime and subprime loans report the results of each separately for maximum precision in the classification. However, the prime sample contains some subprime loans, and the subprime sample some prime loans. Also, there is no separate category for so-called altA mortgages, which are loans to borrowers with high credit scores that are lower in quality on other metrics such as income documentation or loan-to-value ratios. My understanding is that alt-A loans are largely included in the "prime" sample.

10. Foote and others (2008a). 
credit loss estimate is consistent with a given path for home prices, and the present analysis does provide an answer to this question.

Third, because the foreclosure data used here do not pertain to specific mortgage vintages, one cannot control directly for the effects of good versus bad underwriting standards in particular vintages, nor can one precisely estimate foreclosures on the currently outstanding stock of mortgages. The approach could lead to a higher or a lower number than a true "lifetime loss" analysis, depending on whether the losses on mortgages that have yet to be originated but will be realized in the 2008-12 period are greater or smaller than the losses on mortgages that have already been originated but will not be realized until after 2012. I suspect that the difference between these two numbers-whether positive or negative-is small relative to the range of potential estimates, but there is no way to be sure.

\section{Estimates of the Impact of Home Price Changes on Foreclosures}

The odd-numbered columns in table 1 report my baseline estimates of the effects of changes in home prices on foreclosures for subprime ARMs, subprime FRMs, prime ARMs, and prime FRMs. All equations include both state and time dummies. Although time dummies pose some problems for projection purposes, as it is difficult to be sure what number to use for future periods (see the discussion below), I found that equations without time dummies resulted in a significant overprediction of foreclosures in some of the boom-bust states toward the very end of the sample period. This problem was particularly severe for subprime ARMs. When time dummies are included, the overprediction problem is reduced significantly. One potential explanation is that part of the deterioration in the 2006-07 period reflects poor underwriting standards and mortgage fraud in the 2006 and 2007 vintages rather than the impact of home price declines per se. A specification without time dummies will miss such vintage effects. It will attribute all of the deterioration to the home price decline and therefore predict a closer relationship between home price declines and foreclosures than is appropriate if there are indeed important vintage effects.

The upshot of these results is that the link between home price changes and foreclosures is very close. For all four types of mortgages, the relationship is highly significant, with coefficients that sum to between -8.4 and -10.8 . If the lagged dependent variables are ignored, this means that a 1 percent drop in home prices is associated with an 8.4 to 10.8 percent increase in foreclosures. Moreover, there is substantial persistence in all four equations, with coefficients on the lagged dependent variables that sum to between 0.49 and 0.76 . In general, the equations show that prime 
and subprime mortgage foreclosures are quite similar in terms of their links with home prices. The level of foreclosure starts is much higher for subprime loans, and particularly for subprime ARMs, but the elasticity with respect to home prices is not too different. In fact, if anything the elasticity of foreclosure starts to home price declines is slightly higher in the prime market than in the subprime market.

These baseline estimates do not include state-specific economic variables such as the state unemployment rate. ${ }^{11}$ I found little evidence that state unemployment rates have significant predictive power with respect to foreclosures, at least once the model includes the home price and the lagged dependent variable terms. This is illustrated in the regressions reported in the even-numbered columns in table 1, which add the current state unemployment rate and three lags to the baseline specifications. In all four cases the coefficients sum to around zero, with negative coefficients on the current unemployment rate and positive coefficients (in three of the four estimates) on the thrice-lagged unemployment rate. Taking this result seriously would imply that a rising unemployment rate was associated with fewer foreclosures. However, the effect is extremely small. For example, the equation for subprime ARMs implies that a 1-percentage-point increase in the unemployment rate-a very large move on a quarter-toquarter basis-lowers foreclosure starts by just 3 percent (logarithmically). Hence, in what follows I ignore the unemployment rate and instead use the baseline results (the odd-numbered columns) to project alternative paths for overall mortgage credit losses for given home price paths. To be able to do this, one needs to make a number of assumptions, which I now discuss in turn.

\section{Projecting Foreclosure Starts}

To use the model to project foreclosure starts, one needs to choose assumptions for the explanatory variables, namely, state home prices and the time dummies. Regarding state home prices, I choose three paths that are each statistically consistent with one of the following assumptions: a further 5 percent (logarithmic) decline in nominal home prices from their 2008Q2 level, a further 15 percent decline, and a further 25 percent decline, all through the middle of 2009 and measured by the national Case-Shiller index. To translate these national-level home price assumptions to the state level, I use the predicted values from 51 simple regres-

11. National-level variables such as mortgage rates cannot be included because of the time fixed effects. 


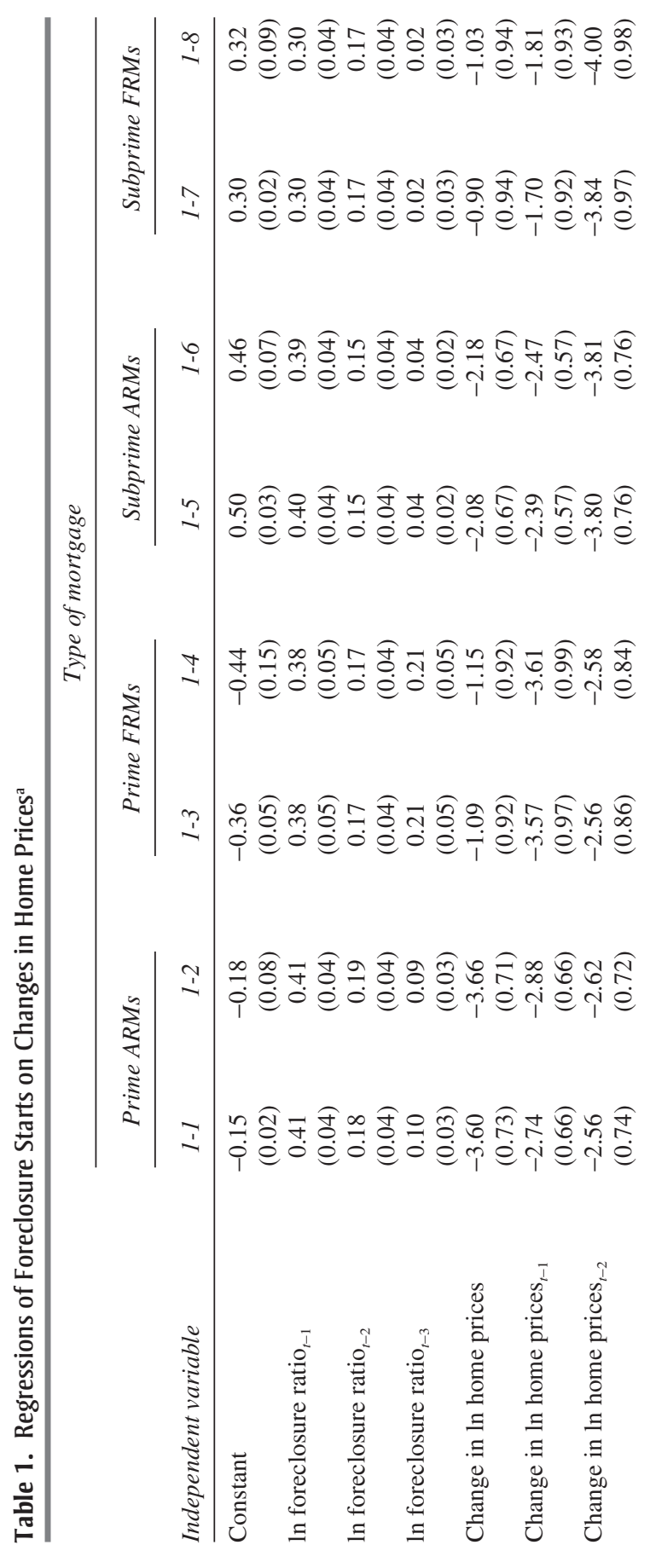




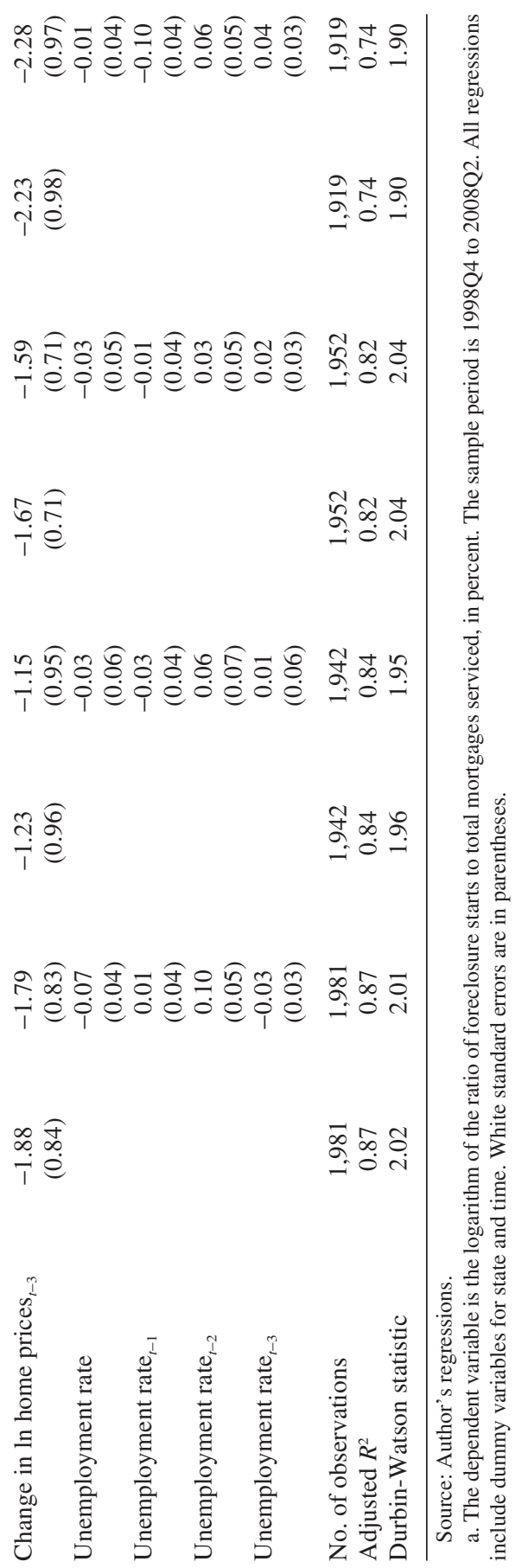


sions (results not reported) of the quarter-to-quarter change in the regional purchase-only OFHEO index on the change in the national Case-Shiller index (both seasonally adjusted using the Census X-12 algorithm). This allows alternative expectations for national home prices, expressed in terms of the Case-Shiller index, to be translated into corresponding assumptions about state-level prices, which are available only from OFHEO. As one might expect, states with volatile housing markets, such as California and Florida, show much greater sensitivity to changes in national home prices than do states with more stable housing markets, such as Iowa and Missouri. ${ }^{12}$

I set the time dummies to zero, which indicates that the time effect is assumed equal to the average of the sample period, under the assumption that the positive time dummies in the 2006-07 period reflect vintage effects resulting from poor underwriting or mortgage fraud, and that these poorly underwritten or fraudulent mortgages have now largely defaulted. This is an important and relatively optimistic assumption, since the time dummies have been mostly positive in recent quarters. ${ }^{13}$ Finally, to estimate the absolute number of foreclosure starts, I multiply all foreclosure rates by the number of mortgages serviced for each state and mortgage type, adjusted for the rising coverage of the MBA sample. ${ }^{14}$

Figure 2 shows actual foreclosure starts since the beginning of 2007 along with my projections through 2012, assuming a further 15 percent home price decline (my central scenario). The model predicts that foreclosure starts will peak at around 530,000 (not annualized) in the fourth quarter of 2008 before gradually falling back toward the levels seen in early 2007 (around 200,000). In total, the model predicts 8.3 million foreclosure starts from early 2007 to late 2012, with projected shares of 37 percent for subprime ARMs, 16 percent for subprime FRMs, 21 percent for prime ARMs, and 26 percent for prime FRMs.

12. Moreover, the predicted values for the national purchase-only OFHEO index that result from aggregating the 51 state predictions are very close to the actual national series, with an $R^{2}$ of 85 percent.

13. If one instead set the time dummies equal to the values estimated for 2008Q2, the projected foreclosure rates would be 15 percent higher for subprime ARMs, 21 percent higher for prime ARMs, 8 percent higher for subprime FRMs, and 15 percent higher for prime FRMs.

14. The total number of mortgages serviced in the MBA dataset as a share of all firstlien home mortgages outstanding according to the American Housing Survey has risen from 57 percent in 1998 to 88 percent in 2008. 
Figure 2. Projected Foreclosure Starts Assuming a Further 15 Percent Home Price Decline, by Mortgage Type, 2007-2012

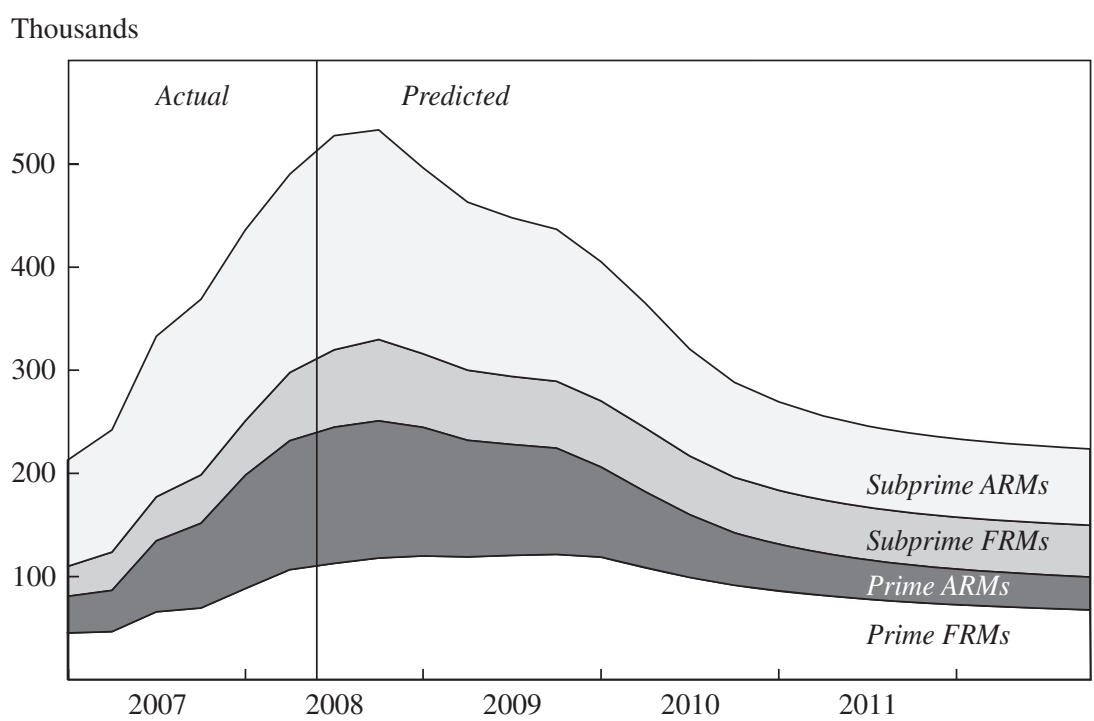

Sources: Standard \& Poor's, Fiserv, MacroMarkets, Mortgage Bankers Association, and author's calculations.

\section{Projecting Loss Incidence and Severity}

The MBA data pertain to foreclosure starts rather than credit losses. Hence, to estimate the latter, one needs to make assumptions about the share of foreclosure starts that result in a loss to the lender, whether through seizure of a home (the "foreclosure completion rate") or not, and about the average size ("severity") of that loss.

Regarding the first issue, the question is what happens to borrowers against whom a foreclosure notice has been filed. In theory, there are a number of possibilities. They could again become current on their mortgage of their own volition (which implies no loss to the lender), lose their home in a sheriff's auction (a large loss to the lender), agree to a "short sale" in which the lender accepts the proceeds even though it falls short of the mortgage balance (usually a somewhat smaller loss), or agree to a repayment plan that may involve some debt forgiveness (an even smaller loss).

Unfortunately, no hard data are available on the relative frequencies of these ultimate outcomes. However, there is good reason to believe that a large proportion of the foreclosures started over the next couple of years 
Table 2. Foreclosure Starts and Sales of Foreclosed Homes in Four States, 2007-08

\begin{tabular}{|c|c|c|c|c|c|c|c|c|}
\hline \multirow[b]{2}{*}{ Quarter } & \multicolumn{2}{|c|}{ California } & \multicolumn{2}{|c|}{ Florida } & \multicolumn{2}{|c|}{ Arizona } & \multicolumn{2}{|c|}{ Nevada } \\
\hline & Starts & Sales & Starts & Sales & Starts & Sales & Starts & Sales \\
\hline 2007Q1 & 28,656 & 7,417 & 18,690 & 2,527 & 4,342 & 1,034 & 3,499 & 979 \\
\hline 2007Q2 & 32,572 & 10,967 & 21,735 & 3,435 & 5,364 & 1,397 & 4,258 & 1,395 \\
\hline 2007Q3 & 47,119 & 15,533 & 32,285 & 5,110 & 6,992 & 2,362 & 4,708 & 1,781 \\
\hline 2007Q4 & 52,348 & 22,348 & 42,639 & 6,200 & 9,260 & 3,494 & 6,807 & 2,740 \\
\hline 2008Q1 & 81,684 & 36,581 & 58,496 & 9,780 & 14,646 & 6,290 & 9,434 & 4,489 \\
\hline 2008Q2 & 99,125 & 56,953 & 72,418 & 14,788 & 19,164 & 10,273 & 12,241 & 7,163 \\
\hline
\end{tabular}

Source: Hope Now, "July State Data 2008."

will result in a significant cost to the lender, in most cases a sheriff's auction. This is partly for a priori reasons. Presumably, negative equity sharply decreases a homeowner's incentive to become current on the mortgage, which would suggest that the percentage of foreclosure starts that result in a cost to the lender will increase as home prices decline. Indeed, this is largely confirmed by data from Hope Now on recent foreclosure starts and sales in states that have already seen large-scale home price declines for several quarters, and where the impact of negative equity on borrower behavior should therefore be most readily apparent. ${ }^{15}$ Table 2 shows that in three of these states (California, Arizona, and Nevada) the number of foreclosure sales is currently running about even with the number of foreclosure starts two quarters earlier. Given the usual foreclosure timeline, this suggests that the vast majority of foreclosure starts currently result in sheriff's auctions in these states. The exception to this pattern is Florida, where foreclosure sales are running at only about one-third the level of foreclosure starts two quarters earlier. However, Florida is a "judicial" state, where lenders need to obtain a court order to proceed with the foreclosure, and a serious logjam in processing foreclosures in the Florida court system has been widely reported. If this is so, most of the foreclosures currently started may still end up resulting in foreclosure sales, but the lag would be too long for this to show up in the foreclosure sales data in the near term.

Moreover, a longer perspective for the state of California confirms that the percentage of foreclosure starts that result in sales closely tracks

15. Hope Now is a coalition of mortgage servicers and other market participants that have committed themselves to preventing foreclosures in cooperation with the Treasury Department. 
Figure 3. California: Foreclosure Starts and Sales of Foreclosed Homes, 1992-2008

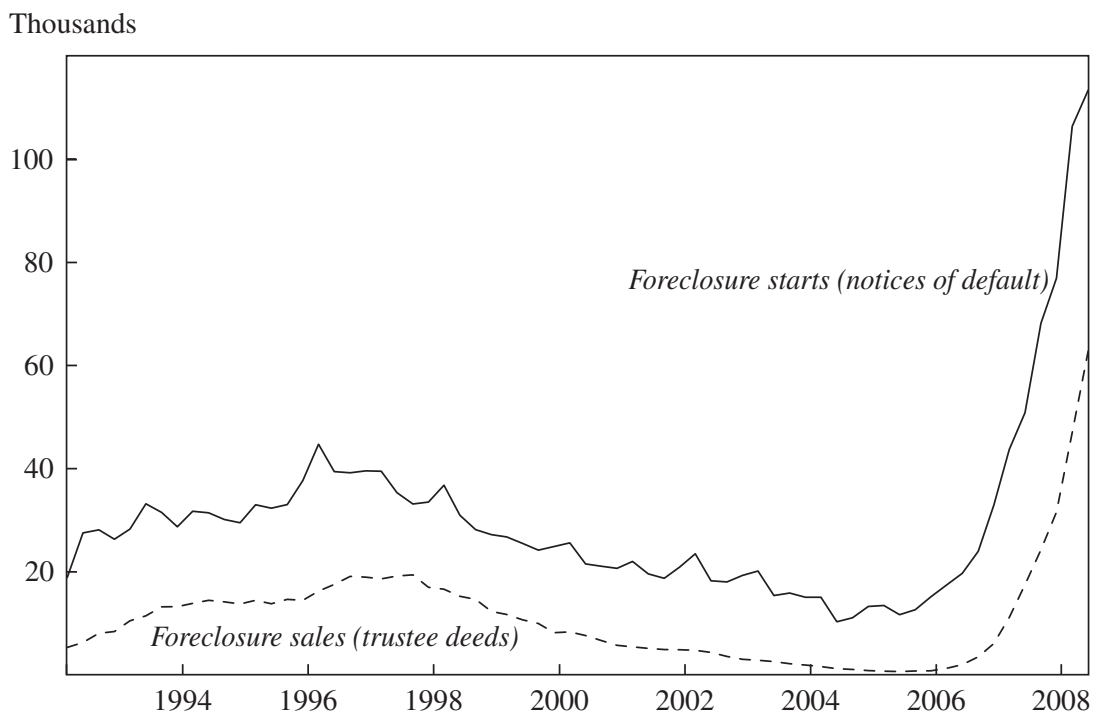

Source: DataQuick Information Systems.

overall housing and mortgage market developments. The real estate information company DataQuick has produced a quarterly time series on foreclosure starts (notices of default) and foreclosure sales (trustee deeds) for California since 1992 (figure 3). ${ }^{16}$ In the downturn of the early to mid1990s, when nominal home prices fell moderately, a sizable proportion of foreclosure starts turned into foreclosure sales. During the California real estate boom that started in the late 1990s, hardly any foreclosure starts turned into sales. Finally, in the home price plunge of the past 12 to 18 months, foreclosure sales have climbed essentially in lockstep with foreclosure starts one to two quarters earlier, confirming that a very large proportion of all new foreclosure starts now result in sales.

These observations suggest that a very large proportion of foreclosure starts in the current cycle will involve a significant loss to the lender, in most cases because a foreclosure start is followed by an eventual sheriff's auction. Moreover, the data suggest that loss incidence shows a strong

16. The absolute numbers are higher than those in table 2 because the DataQuick figures are a universe count whereas the Hope Now figures are based on a sample of servicers. However, the changes over time are quite similar for the (short) period during which both series overlap. 
inverse relationship with changes in home prices. Unfortunately, this relationship cannot be estimated empirically from available data. Instead I assume a foreclosure completion rate of 75 percent if home prices drop another 5 percent from mid-2008 levels, 85 percent if prices drop another 15 percent, and 95 percent if prices drop another 25 percent. ${ }^{17}$

The predicted number of foreclosures must also be converted into dollar losses. Since the MBA foreclosure data are based on the number rather than the dollar value of loans, this requires making an assumption about the average mortgage balance by state. To do this, I use data from the Federal Reserve Bank of New York on the average balances of subprime and alt-A loans by state. I assume that the typical foreclosure in the MBA categories "subprime ARMs" and "subprime FRMs" involves an average-sized subprime loan, and that the typical foreclosure in the MBA categories "prime ARMs" and "prime FRMs" is an average-sized alt-A loan. ${ }^{18}$

The only remaining issue is what to assume for average severity. Severity depends inversely on home prices because a larger home price decline implies that the typical foreclosed home is more deeply in negative equity. Like the foreclosure completion rate, however, the relationship between home prices and severities cannot be estimated statistically from available data. Instead I assume that-depending on the home price outcomeseverities vary between 58 and 68 percent for subprime mortgages and between 39 and 45 percent for prime and alt-A mortgages. ${ }^{19}$

17. One can loosely justify these assumptions by cross-sectionally correlating the 2008Q2 foreclosure completion rate from the Hope Now data (estimated using the ratio of foreclosure sales to foreclosure starts two quarters earlier) with the cumulative home price change from 2006Q2 to 2008Q2. An ordinary least squares regression with 51 observations yields a slope coefficient of -1.35 (with a $t$ statistic of -5.6 ), meaning that an incremental 10-percentage-point home price drop implies an incremental 13.5-percentage-point rise in the foreclosure completion rate.

18. This is a relatively conservative assumption. The MBA subprime sample includes at least a small number of alt-A loans (which are generally larger than subprime loans), and the MBA prime sample includes most jumbo loans (which are generally larger than alt-A loans). Moreover, it is likely that the average foreclosure involves a larger-than-average mortgage balance, since an excessive amount of debt presumably is a key reason the borrower experienced problems in the first place.

19. This assumption is qualitatively consistent with the methodology of Standard \& Poor's (2008), whose severity assumptions depend directly on the decline in home prices. A sampling of recent severity estimates for different mortgage types shows that Standard \& Poor's (2008) assumes prime jumbo, alt-A, and subprime severities of 30, 40, and 50 percent, respectively; Freddie Mac (2008) assumes average alt-A severities of 45 percent; and Goldman Sachs (2007) assumes subprime severities of 60 percent. 
Table 3. Projected Mortgage Credit Losses by Quarter and by Mortgage Type under Three Home Price Scenarios, 2007-12

Billions of dollars

\begin{tabular}{|c|c|c|c|}
\hline \multirow{2}{*}{$\begin{array}{l}\text { Period or type } \\
\text { of mortgage }\end{array}$} & \multicolumn{3}{|c|}{$\begin{array}{l}\text { Loss assuming indicated decline in } \\
\text { home prices from mid-2008 level }\end{array}$} \\
\hline & 5 percent & 15 percent & 25 percent \\
\hline \multicolumn{4}{|l|}{ By quarter } \\
\hline 2007Q1 & 5 & 5 & 5 \\
\hline 2007Q2 & 8 & 8 & 8 \\
\hline 2007Q3 & 13 & 13 & 13 \\
\hline 2007Q4 & 19 & 19 & 19 \\
\hline 2008Q1 & 27 & 27 & 27 \\
\hline 2008Q2 & 37 & 37 & 37 \\
\hline 2008Q3 & 43 & 48 & 53 \\
\hline 2008Q4 & 44 & 52 & 72 \\
\hline 2009Q1 & 38 & 54 & 91 \\
\hline 2009Q2 & 34 & 52 & 107 \\
\hline 2009Q3 & 30 & 50 & 102 \\
\hline 2009Q4 & 27 & 49 & 82 \\
\hline 2010Q1 & 24 & 44 & 60 \\
\hline 2010Q2 & 22 & 39 & 47 \\
\hline 2010Q3 & 20 & 34 & 40 \\
\hline 2010Q4 & 19 & 30 & 35 \\
\hline 2011Q1 & 19 & 27 & 33 \\
\hline 2011Q2 & 18 & 26 & 31 \\
\hline 2011Q3 & 18 & 24 & 29 \\
\hline 2011Q4 & 17 & 24 & 28 \\
\hline 2012Q1 & 17 & 23 & 27 \\
\hline 2012Q2 & 17 & 23 & 27 \\
\hline 2012Q3 & 17 & 22 & 26 \\
\hline 2012Q4 & 17 & 22 & 26 \\
\hline \multicolumn{4}{|c|}{ By type of mortgage } \\
\hline Subprime ARMs & 218 & 291 & 391 \\
\hline Subprime FRMs & 87 & 110 & 134 \\
\hline Prime ARMs & 119 & 173 & 264 \\
\hline Prime FRMs & 126 & 175 & 234 \\
\hline Total, 2007-12 & 550 & 750 & 1,023 \\
\hline
\end{tabular}

Source: Author's calculations.

\section{Credit Loss Projections}

I use the above assumptions to project total credit losses for three alternative price scenarios, as reported in the top panel of table 3. If nominal home prices fall another 5 percent before reverting to the previous trend, in which prices rose by an average of 3 percent a year, the model implies that mortgage 
credit losses realized in 2007-12 will total $\$ 550$ billion. If instead nominal home prices fall another 15 percent through the middle of 2009, the model projects losses of $\$ 750$ billion. Finally, if prices drop another 25 percent, predicted losses increase to $\$ 1.02$ trillion. Moreover, the table suggests that losses peak in the fourth quarter of 2008 if home prices drop another 5 percent; in the first quarter of 2009 if prices drop another 15 percent; and in the second quarter of 2009 if prices drop another 25 percent. ${ }^{20}$

The bottom panel in table 3 reports total estimated losses in the above three home price scenarios for each type of mortgage. In the central scenario (home prices fall by 15 percent), the model implies that losses of $\$ 402$ billion (with rounding), or just over half of all losses, will occur in the subprime sector. As it happens, this corresponds roughly to the subprime losses currently implied by prices of the ABX.HE family of subprime credit derivatives. ${ }^{21}$ One could interpret this as saying that the market is currently discounting an implicit further home price decline of just under 15 percent. However, this statement is highly approximate because the $\mathrm{ABX}$ analysis is based on the stock of mortgages currently outstanding, whereas my analysis of the MBA foreclosure data is based on projected cumulative foreclosures over the 2007-12 period.

\section{The Link between Credit Losses and Lending}

The main reason why credit losses are important from a macroeconomic perspective is that they weigh on the supply of credit to nonfinancial borrowers. In this section I use the mortgage credit loss estimates of the previous section to quantify this link.

I start by documenting the facts about credit extension. About half of the nearly $\$ 50$ trillion in total credit extended by U.S.-based entities consists of liabilities by domestic nonfinancial private borrowers; the rest is mainly financial and government debt. I focus here on the availability of credit to private nonfinancial borrowers because it is likely to have the most direct effect on overall economic activity. ${ }^{22}$

20. Losses are dated as of the foreclosure start, since this usually coincides roughly with the booking of a loss by the lender. If the date of foreclosure sale were used instead, the peaks would occur roughly two quarters later.

21. According to the model developed in Goldman Sachs (2007), the ABX.HE market was discounting total subprime losses of $\$ 388.5$ billion as of November 3, 2008.

22. Reduced availability of financial credit may be important indirectly, but such an effect would usually work by way of a tightening of nonfinancial lending conditions. A reduction in credit availability to government borrowers is unlikely except in extreme cases. 
Figure 4. Outstanding Debt of Private Nonfinancial Borrowers, Second Quarter 2008

Trillions of dollars

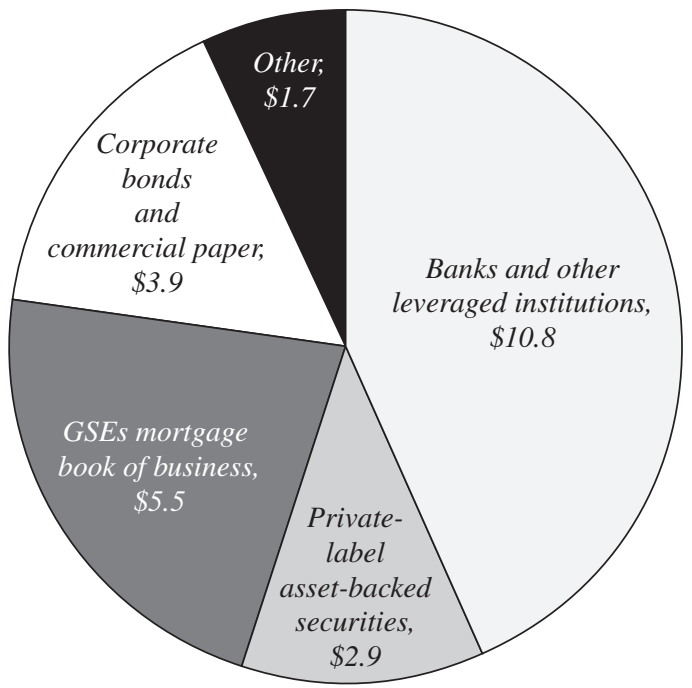

Source: Board of Governors of the Federal Reserve.

Using information from the Federal Reserve Board's flow of funds accounts as well as my own assumptions and interpolations, one can divide this debt into five main categories (figure 4):

-On-balance-sheet lending by leveraged private entities ( $\$ 10.8$ trillion as of the second quarter of 2008). These include banks, broker-dealers, savings institutions, and finance companies. The largest categories are residential and commercial mortgages held on balance sheet, followed by other bank loans and consumer credit held on balance sheet. (This measure of on-balance-sheet lending does not include GSE-backed mortgagebacked securities, or MBSs, for which the credit risk ultimately resides with a government agency.)

-Lending in the ABS markets ( $\$ 2.9$ trillion). This category mostly consists of nonconforming mortgage-backed securities, but it also includes securities backed by consumer credit and corporate loans. This figure excludes ABSs held on the balance sheets of leveraged institutions.

—Debt owned or guaranteed by a GSE ( $\$ 5.5$ trillion). This category consists almost entirely of the mortgage books of business of Fannie Mae and Freddie Mac, which include mortgages or MBSs on their balance sheets as well as MBSs for which those institutions bear the credit risk. I 
Figure 5. Accounting for Growth in Nonfinancial Private Credit, 1991-2008

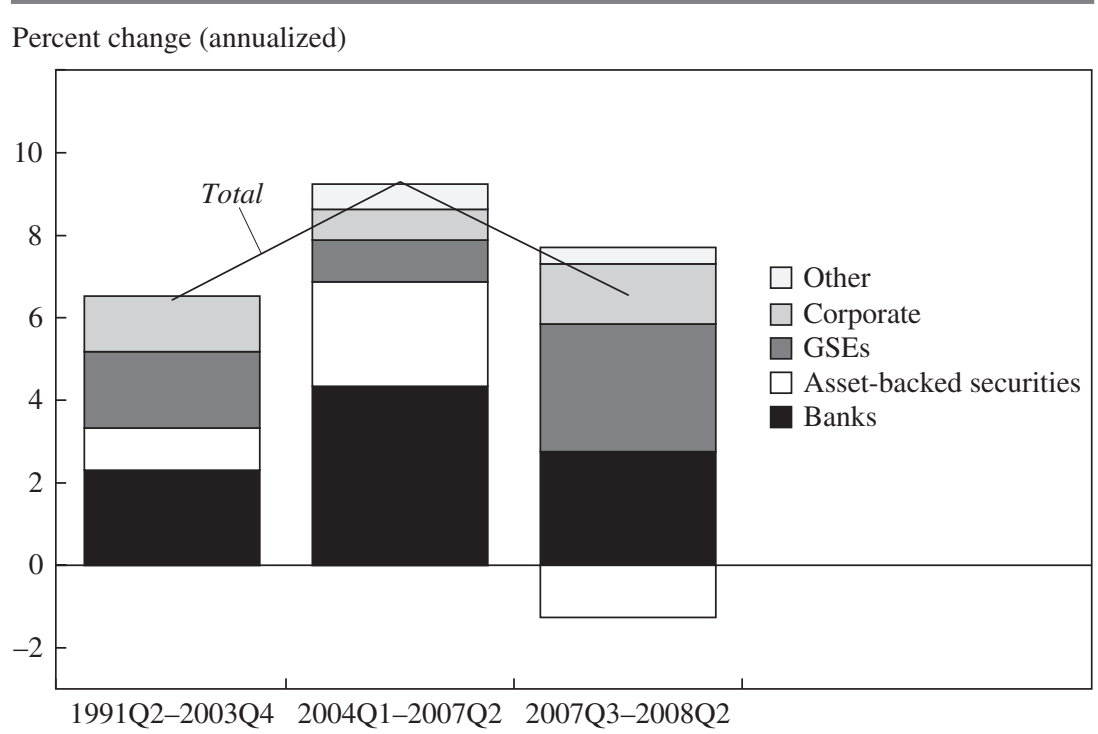

Source: Board of Governors of the Federal Reserve.

include mortgages held on a private sector balance sheet so long as the GSEs bear the credit risk.

-Lending in the corporate bond and commercial paper markets (\$3.9 trillion). This figure again excludes assets held on the balance sheets of leveraged institutions.

—Direct lending and holdings of securities by unleveraged entities (\$1.7 trillion). These include insurance companies, pension funds, and the government.

Figure 5 shows total private nonfinancial credit growth and its five components since 1991. Overall credit has grown at a compound annual rate of 7.1 percent, significantly faster than the 5.3 percent annual growth rate of nominal GDP over that period. By far the biggest contributor has been onbalance-sheet credit growth, which has contributed 2.7 percentage points, followed by GSE lending with 1.8 percentage points, corporate bonds with 1.2 percentage points, and the ABS markets with 1.1 percentage points.

However, the relative contributions of these different sectors have changed sharply over time. During the credit boom of the 2004-07 period, the surge in the private-label securitization markets contributed as much as 2.5 percentage points to overall credit growth. Since the start of the bust in mid-2008, however, this picture has changed dramatically, as the 
private-label ABS market has subtracted 1.3 percentage points from overall credit growth. In contrast, GSE-backed lending has accelerated sharply over the past year. During the boom, GSE-backed lending contributed 1.0 percentage point to credit growth, but since the bust started this number has increased to 3.1 percentage points. This acceleration has come despite the deterioration in the finances of Fannie Mae and Freddie Mac over that period.

Of particular interest in assessing the impact of the credit crisis are the first three sectors: leveraged institutions, private-label ABS markets, and the GSEs. The next subsection discusses the likely behavior of each of these in turn.

\section{The Behavior of Leveraged Financial Institutions}

The first shock to the supply of credit occurs through declining equity capital and declining leverage among financial institutions, including commercial banks, broker-dealers, savings institutions, credit unions, and finance companies. In what follows I refer to this entire group of leveraged institutions simply as "banks."

There are three key ingredients in this story, which follows GHKS in several important respects. First, the losses and writedowns cut into banks' equity capital base, despite offsets to these losses from recapitalization as well as lower corporate income taxes. ${ }^{23}$ Second, the impact is magnified because banks appear to target a procyclical leverage ratio over the business cycle. This can be explained in terms of value-at-risk models that measure the approximate maximum daily loss ("approximate" in the sense that anything worse than this loss can only happen with some benchmark probability). Third, the impact of the first two factors on end-user credithouseholds and nonfinancial businesses-is dampened because some of the lost credit supply consists of claims on other banks.

To get an estimate of the impact on credit supply, one can summarize this story by means of the following equations:

$$
\begin{gathered}
\mathrm{d} A=[-C \times(1-k-t) \times L]+(\mathrm{d} L \times A) \\
\mathrm{d} Y=\mathrm{d} A \times Y / A,
\end{gathered}
$$

23. The analysis of the offsets in this paper focuses only on private sector recapitalization. Government equity injections are discussed as part of the policy response in the final section. 
Table 4. Worldwide Credit Losses by Type of Financial Institution since Mid-2007ª

Billions of dollars

\begin{tabular}{lcccr}
\hline Type of institution & United States & Europe & Rest of world & Total \\
\hline Investment banks & 126.3 & 78.7 & 0.9 & 205.9 \\
Commercial banks & 370.3 & 112.4 & 14.2 & 496.9 \\
Specialty finance & 91.6 & $\ldots$ & $\ldots$ & 91.6 \\
$\begin{array}{l}\text { Insurance and asset } \\
\text { management firms }\end{array}$ & 38.8 & 6.6 & $\ldots$ & 45.4 \\
$\quad$ & & & & \\
Total & 627.0 & 191.7 & 15.1 & 839.8 \\
\hline
\end{tabular}

Sources: Company releases, Goldman Sachs Research.

a. Losses include writedowns, above-trend provisions, and equity in failed institutions.

where $A$ is total bank assets (the total size of the unconsolidated balance sheet), $Y$ is end-user credit (lending to private nonfinancial entities), $C$ is the pre-tax credit loss suffered by banks, $k$ is the percentage of pre-tax credit losses that is replaced by raising capital, $t$ is the effective marginal corporate income tax rate, and $L$ is leverage. To derive a benchmark for the contraction in total assets and nonfinancial private credit, I use the following numbers for the variables in equations 1 and 2 :

$\begin{array}{lr}\text { Bank credit loss }(C) & \$ 762 \text { billion } \\ \text { Tax offset }(t) & 25 \text { percent } \\ \text { Private recapitalization rate }(k) & 50 \text { percent } \\ \text { Change in leverage }(\mathrm{d} L) & -10 \text { percent } \\ \text { End-user credit ratio }(Y / A) & 63 \text { percent. }\end{array}$

I explain each of these assumptions in turn.

BANK CREDIT LOSS. For my illustrative calculation, I assume that home prices fall by another 15 percent (logarithmically) from mid-2008 to mid2009, which, according to the model developed in the previous section, should result in a total credit loss on residential mortgages of $\$ 750$ billion. I assume that U.S. banks ultimately suffer 60 percent of this loss, or $\$ 450$ billion. Table 4 summarizes credit losses realized since the crisis began in the summer of 2007. Over the past year, financial institutions globally have written down or provisioned for a total of $\$ 840$ billion because of the credit crisis, mostly because of residential mortgages. (This figure includes about $\$ 100$ billion of equity capital lost in failed financial institutions.) U.S. commercial banks and investment banks account for $\$ 497$ billion (59 percent) of this total. My assumption that U.S. banks will bear 60 percent of the ultimate loss simply reflects their share in losses recognized to date.

In addition to the assumed $\$ 450$ billion in residential mortgage credit losses, banks are starting to see larger credit losses on other types of loans 
and ABSs, including commercial mortgages and consumer credit. To incorporate these into the analysis, I use the estimates provided by the International Monetary Fund (IMF). ${ }^{24}$ Specifically, I use the midpoint of the IMF's ranges for bank losses on loans and securities exposures other than residential mortgages, residential MBSs, and residential ABS collateralized debt obligations. For loans, I assume that all bank losses are incurred by U.S. institutions; for securities, I assume that 60 percent of all bank losses are incurred by U.S. institutions. This results in additional estimated losses and writedowns for U.S. banks of $\$ 312$ billion, for a total estimated loss, including residential mortgages, of $\$ 762$ billion.

TAX OFFSET. The after-tax credit loss is likely to be lower than the pretax loss because most banks will be able to use their credit losses to lower their corporate income tax liability. However, the offset is likely to be below the statutory 35 percent corporate income tax rate. Banks that make losses for many years - or end up going out of business - will be unable to obtain this offset. Taking this into account, I assume that the average effective marginal tax rate offset is 25 percent.

PRIVATE RECAPITALIZATION RATE. So far during the crisis, U.S. commercial and investment banks have raised about 65 percent of the total pre-tax credit loss in new equity capital. More recently, however, the pace of private recapitalization has slowed as the crisis has intensified. I therefore assume a somewhat smaller ultimate private recapitalization ratio of 50 percent, in line with the central assumption in GHKS.

CHANGE IN LEVERAGE. GHKS show that leverage by commercial and investment banks is procyclical, rising in booms and declining in slumps. However, their paper does not provide much guidance with respect to the size of the potential leverage decline during the current crisis. To obtain a quantitative estimate, I therefore look at two other pieces of evidence: the history of the early 1990s, and recent disclosures by U.S. banks of changes in their balance sheet targets.

Figure 6 plots the aggregate leverage ratio of U.S. banks (both commercial and investment banks) since $1990 .{ }^{25}$ It shows that leverage declined by 28 percent (from 17.0 to 12.3 ) in the four years from 1990 to 1994. If this

\section{4. $\operatorname{IMF}(2008)$.}

25. I define leverage as total assets divided by equity capital. The series is calculated from quarterly financial reports on the assets and equity capital of firms included in the following S\&P 500 sectors: diversified banks (GICS code 40101010), regional banks (40101015), other diversified financial services (40201020), and investment banking and brokerage (40203020). The series is adjusted for two series breaks in June 2003 and April 2005. 
Figure 6. Bank Leverage Ratios, 1990-2008

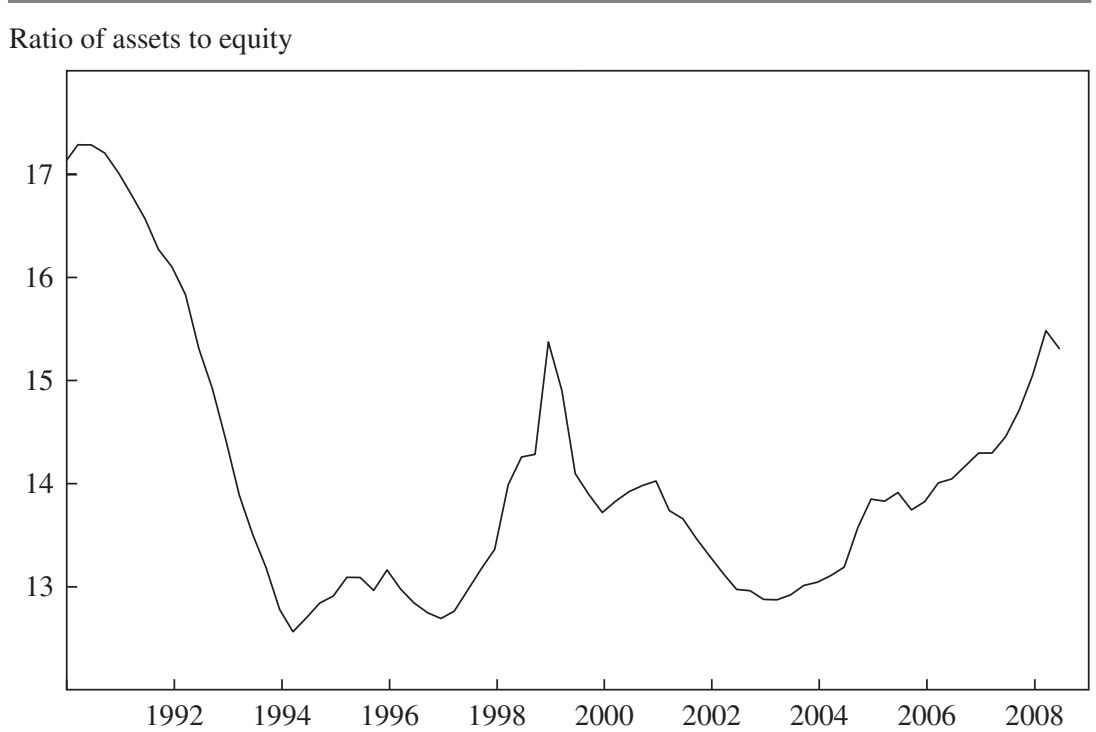

Sources: Standard \& Poor's and author's calculations.

a. Data cover both commercial and investment banks.

were to be the template for the current crisis, it would imply a very large amount of deleveraging. However, the figure also shows that leverage in the banking system is now lower than it was in 1990. This suggests that the decline in leverage among banks could be a bit more muted. ${ }^{26}$ Hence, I assume a decline in overall bank leverage of 10 percent, while acknowledging that the uncertainty about target leverage is sizable and that the risks are probably tilted in the direction of a larger decline. ${ }^{27}$

END-USER CREDIT RATIO. In the dataset for this paper, the ratio of enduser credit to total bank assets is 63 percent, calculated simply as the ratio of private nonfinancial credit to the total size of the unconsolidated

26. The analysis in this section excludes off-balance-sheet vehicles. However, the shrinkage of the off-balance-sheet ABS markets is discussed below.

27. In terms of the leverage ratio, I rely on the estimates in exhibit 4.5 in GHKS, rather than the bottom-up data in figure 6. Although the bottom-up data are suitable for assessing changes over time, they include S\&P 500 firms only and exclude both finance companies and most savings institutions and are therefore considerably less comprehensive. When adjusted for the exclusion of the GSEs and imputed hedge fund figures from the leveraged sector, the GHKS data imply an aggregate leverage ratio of 10.9 . 
bank balance sheet. This is larger than the 42.7 percent share used in GHKS, which was estimated indirectly (and for a somewhat different set of institutions) from various accounting relationships in the U.S. banking sector. However, the 63 percent figure is similar to that reported in the recent study by Deutsche Bank, which estimates an end-user credit share of 67 percent for the European banking system. ${ }^{28}$

Armed with these assumptions, I can calculate benchmark figures for $\mathrm{d} A$ and $\mathrm{d} Y$ as follows:

$$
\mathrm{d} A=[-\$ 762 \text { billion } \times(1-0.50-0.25) \times 10.9]-(0.1 \times \$ 17.3 \text { trillion })=
$$
$-\$ 3.81$ trillion

$$
\mathrm{d} Y=-\$ 3.81 \text { trillion } \times 0.63=-\$ 2.40 \text { trillion. }
$$

Thus, the above assumptions imply that banks could reduce the supply of credit to end users by $\$ 2.4$ trillion in response to credit losses and the change in their desired leverage ratios. This number is more than twice the $\$ 1$ trillion estimate in GHKS, for three main reasons. First, partly because of more adverse mortgage credit loss assumptions, and partly because I also consider nonmortgage credit losses, I assume considerably larger total credit losses for banks, although this difference is partly offset by the assumption that banks will use 25 percent of their losses to reduce their income tax liability. Second, I consider a decline in leverage of 10 percent rather than 5 percent. Third, I assume a larger end-user credit share.

One very important question is the time horizon over which the adjustment takes place. For purposes of quantifying the impact on real GDP growth, I assume that the impact occurs over a two-year period. This is based on the assumption that banks started to respond to the credit crisis in mid- to late 2007 and will have completed their response by mid- to late 2009, when home prices are assumed to bottom. Under this assumption, the combined effects of the losses and the deleveraging would subtract $\$ 1.2$ trillion from the annualized flow supply of end-user bank credit, relative to a baseline scenario in which there is no housing and credit crisis. In this baseline scenario, the most natural assumption is continued bank lending growth that matches the trend annual growth rate of nominal GDP of about 5 percent. Since this implies baseline bank lending of about $\$ 500$ billion a year (calculated as 5 percent $\times \$ 10.9$ trillion), these calcula- 
tions imply an annualized shrinkage in the absolute flow supply of enduser bank credit of $\$ 700$ billion during the crisis. ${ }^{29}$

\section{ABS Market Disruptions}

The second disruption to the supply of credit occurs through the ABS markets. The recent mortgage credit losses have brought the originate-anddistribute model underlying these markets into serious disrepute. That model is based on the idea that the bundling and structuring of small loans-most commonly residential or commercial mortgages, but also credit card debt, student loans, and a host of other loans-combined with an opinion from the major rating agencies can produce securities with risk characteristics comparable to those of traditional corporate bonds. However, the much higher than expected losses on these securities, especially subprime mortgage securities, have badly dented the reputation of the rating agencies and undermined the willingness of investors to purchase such securitized products from the financial institutions that bundle them. Without a respected third-party institution to assess the credit quality of ABSs, the model has broken down. As a result, gross issuance has fallen sharply.

Figure 7 shows the impact of this disruption on overall credit creation. It plots gross issuance of securitized nonconforming residential mortgages, commercial mortgages, credit cards, and automobile and student loans since early 2006, as well as the measure of net lending through the ABS markets discussed above. As gross issuance has fallen from around $\$ 1.3$ trillion (annualized) in 2006 and the first half of 2007 to only around $\$ 500$ billion (annualized) in the second half of 2007 and the first half of 2008, net credit extension through off-balance-sheet ABSs has swung from an average of around $+\$ 600$ billion to $-\$ 300$ billion. Hence, it appears that most of the drop in gross issuance has translated into a drop in net credit extension.

It is unlikely that $\mathrm{ABS}$ issuance will rebound until investors regain confidence in their ability to evaluate ABS credit quality. This could happen in

29. In apparent contrast to predictions of a credit slowdown, the Federal Reserve's weekly commercial bank balance sheet data point to a sharp pickup in bank credit growth since early September 2008. I believe that this pickup reflects a substantial increase in the demand for bank credit as other financing sources have dried up, and is therefore demandrather than supply-driven. For example, a number of corporate borrowers have reportedly been shut out of the commercial paper markets and have therefore tapped backup credit lines. Despite the pickup in credit outstanding, the Federal Reserve's Senior Loan Officers' survey for 2008Q4 shows a clear increase in lending restraint by banks, consistent with the predictions of this analysis. 
Figure 7. Issuance of Asset-Backed Securities, 2007-08

Trillions of dollars ${ }^{\mathrm{a}}$

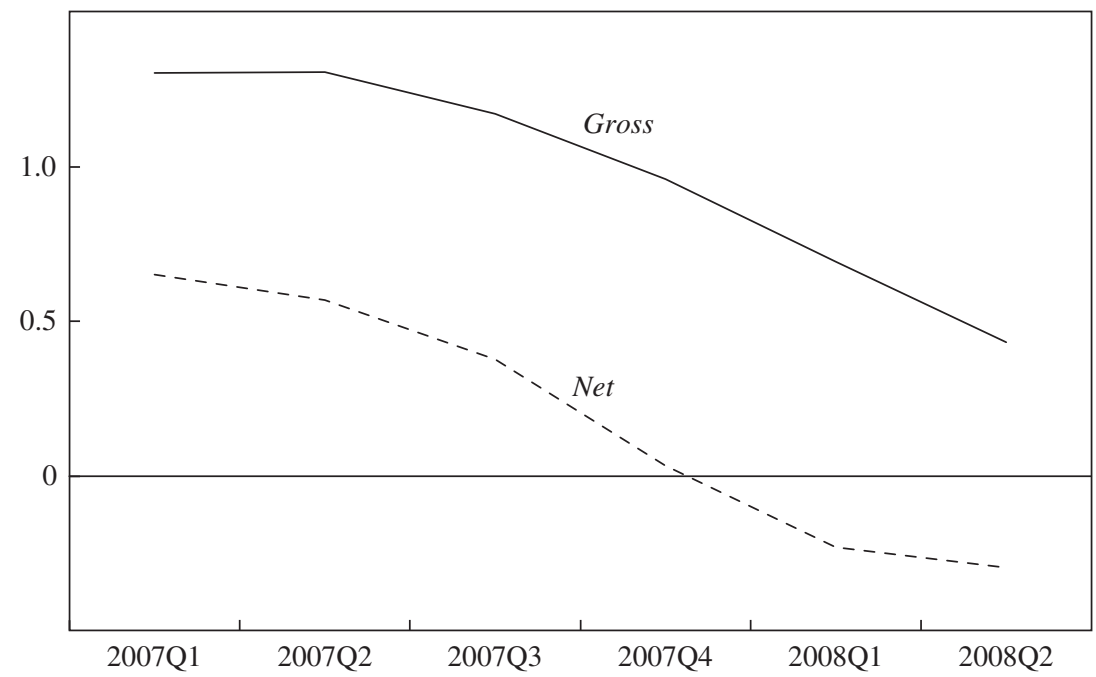

Sources: Board of Governors of the Federal Reserve, Securities Industry and Financial Markets Association, Bloomberg.

a. Sum of preceding four quarters.

one of two ways. Either the rating agencies regain the trust of investors, despite their failure to foresee the massive mortgage credit losses, or investors and issuers come up with alternative methods of monitoring credit quality in the ABS market. Neither development looks imminent, and so it is likely that gross ABS issuance will remain extremely low and net $\mathrm{ABS}$ issuance sharply negative. I therefore assume that net credit extension through the ABS markets will average $-\$ 400$ billion (annualized) in 2008 and 2009. Relative to a counterfactual trend of $+\$ 125$ billion (+5 percent of the outstanding stock of ABSs), this implies an impact of $-\$ 525$ billion.

\section{The Behavior of Government-Sponsored Enterprises}

The GHKS analysis includes the activity of Fannie Mae and Freddie Mac with that of other leveraged financial institutions. This seemed reasonable at the time because the GSEs are clearly among the most highly leveraged institutions in the U.S. financial system, and because they are more directly exposed to the housing market than any other. Now that the 
Figure 8. Changes in GSEs' Mortgage Book of Business, 2004-08

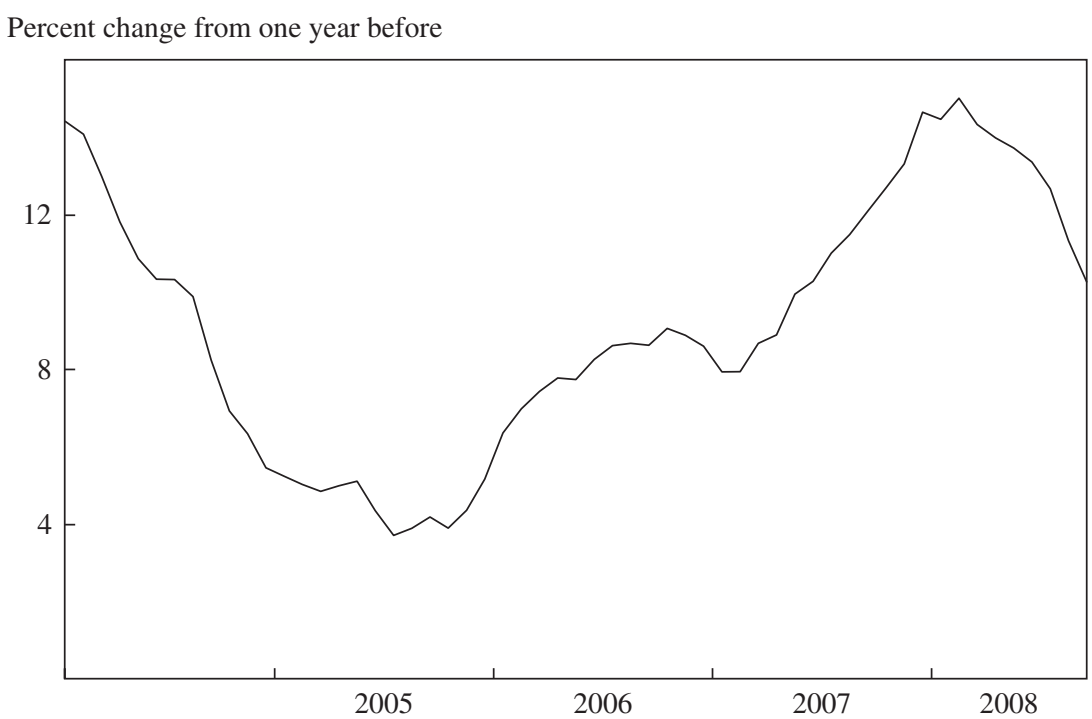

Sources: Freddie Mac, Fannie Mae.

GSEs have been taken into conservatorship by the federal government, however, they clearly need to be analyzed separately.

From the beginning of the financial crisis in August 2007 until about May 2008, the GSEs behaved very differently from other private financial institutions. As shown in figure 8, the GSEs grew their books of business at rates of up to 15 percent and provided a major offset to the tightening in the fully private financial sector. However, starting in June 2008, growth slowed sharply as the GSEs started to focus on capital preservation. The Treasury Department's decision in early September 2008 to take the GSEs into conservatorship raises the likelihood of a renewed pickup in growth. The present analysis assumes that the annualized contribution of the GSEs to overall credit growth will average $\$ 500$ billion, or about 10 percent.

\section{Implications for Overall Credit Supply}

To sum up the discussion, table 5 shows my rough estimates of the net impact from the three sectors on the supply of nonfinancial private credit. This is done by adding up the estimated annualized reduction in the supply of bank credit, the annualized change in off-balance-sheet private-label ABSs relative to a counterfactual assumption of 5 percent annual growth, 
Table 5. Projected Change in Credit Supply by Type of Financial Institution, 2008-09 Billions of dollars

\begin{tabular}{lccc}
\hline Type of institution & $\begin{array}{c}\text { Change in } \\
\text { credit from } \\
\text { end-2007 }\end{array}$ & $\begin{array}{c}\text { Trend credit } \\
\text { growth at } \\
\text { 5 percent a year }\end{array}$ & $\begin{array}{c}\text { Total change } \\
\text { in credit } \\
\text { supply }\end{array}$ \\
\hline $\begin{array}{l}\text { Banks and other leveraged financial } \\
\quad \text { institutions }\end{array}$ & & & $-1,199$ \\
Asset-backed securities markets & -400 & +125 & -525 \\
Government-sponsored enterprises & +500 & +250 & +250 \\
$\quad$ Total & & & $-1,474$ \\
Memorandum: change in credit as & & & -6.0 \\
$\quad$ percent of total credit outstanding & & & \\
\hline
\end{tabular}

Source: Author's calculations.

a. Includes commercial banks, broker-dealers, savings institutions, credit unions, and finance companies.

and the annualized change in GSE-backed debt, also relative to a counterfactual assumption of 5 percent growth. These numbers sum to a total drag on nonfinancial private lending of $\$ 1.47$ trillion, equivalent to a 6.0-percentage-point drag on the growth rate of private nonfinancial debt. This is almost entirely due to the restraint on bank balance sheet growth from credit losses net of recapitalization and falling leverage.

\section{The Link between Lending and Aggregate Economic Activity}

To complete the analysis, I turn to the link between the supply of credit and aggregate economic activity. The effects of the credit losses on banks and off-balance-sheet ABS markets have led to a reduction in overall balance sheet capacity and therefore in the supply of credit to the real economy. A simple way to gauge the importance of this effect is to relate the volume of credit outstanding to a measure of cyclical fluctuation in overall economic activity, such as the growth rate of real GDP. However, since the causality between credit and economic activity clearly runs in both directions, it is important to look for instrumental variables that can be used to isolate the impact of an exogenous change in credit on activity. I use two survey measures of credit availability as instruments. The first is the perceived availability of credit to small businesses, as measured in the monthly survey of the National Federation of Independent Business (NFIB), and the second is the willingness of banks to extend consumer installment loans, as measured in the Federal Reserve's Senior Loan Officers' (SLO) survey. 
Although an instrumental variables (IV) approach should reduce the endogeneity problem, there is also the risk that a tightening of credit availability may be due to a deterioration in the economy, which would render the instruments invalid. ${ }^{30}$ The first-stage equation therefore uses only instruments lagged by two quarters or more. Even this does not entirely rule out endogeneity problems if banks are systematically able to predict a deterioration in the economy two quarters or more in the future and adjust their credit standards accordingly. Whether banks can do this, however, is open to question. The fact that the housing and credit crisis apparently caught many banks by surprise raises serious questions about their ability to forecast broader economic and market developments and reduces the concern about endogeneity in this analysis.

I start with a simple ordinary least squares regression of real GDP growth on real private domestic nonfinancial debt (PDNFD) growth, using quarterly data from 1974Q4 through 2008Q1:

$$
\begin{gathered}
\mathrm{d} G D P=0.0114+0.39309 \mathrm{~d} P D N F D \\
(1.93) \quad(4.17) \\
\text { Adjusted } R^{2}=0.16, \mathrm{SE}=0.028, \mathrm{D}-\mathrm{W}=1.56
\end{gathered}
$$

where $\mathrm{d} G D P$ is the annualized log change in real GDP, $\mathrm{d} P D N F D$ is the annualized log difference of real credit, and Newey-West $t$ statistics are given in parentheses below the regression coefficients. SE is the standard error or the regression, and D-W is the Durbin-Watson statistic. There clearly is a reasonably strong correlation between credit growth and GDP growth, very much as expected.

Turning to the IV results, I start by presenting the results from an auxiliary first-stage regression of credit on the lagged survey variables:

$$
\begin{gathered}
\mathrm{d} \widehat{P D N F D}=0.0752-0.005532 N F I B_{2104}+0.00358 S^{S L O} O_{2 \text { to } 3} \\
(11.71) \quad(4.83)
\end{gathered}
$$

$$
\text { Adjusted } R^{2}=0.51, \mathrm{SE}=0.0226, \mathrm{D}-\mathrm{W}=0.79
$$

where $N F I B_{2}$ to 4 is the average percentage of small businesses indicating in the NFIB survey that credit was harder to get from lags 2 to 4 , and $\mathrm{SLO}_{2 \text { to } 3}$ is the average net percentage of banks reporting in the SLO survey an increased willingness to make consumer installment loans (seasonally adjusted using the Census X-12 algorithm) from lags 2 to 3 . These

30. Mishkin (2008). 
survey variables have substantial predictive power for future private credit growth.

Next, the second-stage IV regression is given by

$$
\mathrm{d} G D P=0.002261+0.443059 \mathrm{~d} \widehat{P D N F D}
$$

Adjusted $R^{2}=0.16, \mathrm{SE}=0.0071, \mathrm{D}-\mathrm{W}=1.55$

where $\mathrm{d} G D P$ is the annualized log difference of real GDP. The equation implies that a supply-driven 1-percentage-point slowdown in real credit growth is associated with a 0.44-percentage-point slowdown in real GDP growth. This estimate is very similar to the results reported by GHKS, who estimate that a 1-percentage-point slowdown in credit growth lowers real GDP growth by 0.34 percentage point in the short run and 0.47 percentage point in the long run.

These regression results can be combined with the calculations in the prior section to estimate the approximate impact of the credit supply deterioration on economic activity. Recall that the estimate of supply-driven drag on credit growth was 6.0 percentage points per year. According to the IV estimates, this implies a drag on real GDP growth of 2.6 percentage points per year for a two-year period.

The above estimates should be interpreted as the shock to aggregate demand from the balance sheet tightening brought about by the increase in mortgage credit losses. The ultimate deviation of real GDP growth from trend could be larger or smaller than this estimate. It could be larger if there are substantial multiplier effects that amplify the initial shock. These multipliers could work through a deterioration in the labor market, a downturn in nonfinancial business investment in response to the original shock, or a U.S.-induced global economic slowdown that washes back onto U.S. shores through effects on international trade and investment. It could be smaller if economic policymakers react to the shock in a timely manner by cutting interest rates and loosening fiscal policy. In addition, the largescale equity injections into the financial sector by the Treasury through the Troubled Asset Relief Program (TARP) have the potential to offset a significant part of the shock from reduced bank lending.

\section{Conclusion}

The analysis in this paper confirms that the decline in home prices and the associated increase in mortgage credit losses have been an important 
driver of the economic downturn through the disruptions in the financial system they have caused. These disruptions result not just from the impact of the losses on the lending capacity of banks, as emphasized by GHKS, but also from the sharp swing from positive into negative territory of net lending in the private-label ABS markets.

From a policy perspective, the analysis suggests that measures to boost the supply of credit are promising tools for softening the current economic downturn. One such measure is the $\$ 700$ billion recapitalization of the financial system being undertaken by the Treasury Department through TARP. As of early November 2008 , the Treasury had committed $\$ 250$ billion in government capital injections into financial institutions through this program. Further injections could significantly soften the current credit squeeze.

Another possibility is to step up the supply of credit through Fannie Mae and Freddie Mac. The baseline assumption of this paper is that the GSEs will grow their book of business by 10 percent (at an annualized rate), or about $\$ 500$ billion. This assumption is actually slightly more optimistic than the pace seen in the six months through September 2008, when the aggregate book of business grew by only 6.3 percent annualized. However, now that the Treasury essentially controls Fannie Mae and Freddie Mac, it could significantly boost the growth rate. The analysis in this paper implies that this would also soften the impact of the squeeze in the banking system and the ABS markets.

ACKNOWLEDGMENTS I am grateful to Charles Himmelberg, Donald Kohn, Nellie Liang, Edward McKelvey, Terence J. O'Neill, Andrew Tilton, and Dominic Wilson for helpful comments. Thanks are also due to Seamus Smyth for help with the models, and to Kent Michels and Shirla Sum for outstanding research assistance. The views expressed in this paper are solely those of the author and not necessarily those of Goldman Sachs. All errors are my own. 


\section{References}

Bank of England. 2008. Financial Stability Report. No. 23. London (April).

Blundell-Wignall, Adrian. 2008. "The Subprime Crisis: Size, Deleveraging, and Some Policy Options.” OECD Financial Market Trends 94, no 2008/1.

Deutsche Bank. 2008. "Unwinding Leverage." Deutsche Bank Global Economic Perspectives (July 28).

Foote, Christopher L., Kristopher Gerardi, Lorenz Goette, and Paul Willen. 2008a. "Subprime Facts: What (We Think) We Know about the Subprime Crisis and What We Don't." Federal Reserve Bank of Boston Public Policy Discussion Paper 08-2. Boston.

Foote, Christopher L., Kristopher Gerardi, and Paul Willen. 2008b. "Negative Equity and Foreclosure: Theory and Evidence." Federal Reserve Bank of Boston Public Policy Discussion Paper 08-3. Boston.

Freddie Mac. 2008. "Freddie Mac's Second Quarter 2008 Financial Results." Washington.

Goldman Sachs. 2007. "The Subprime Issue: A Global Assessment of Losses, Contagion, and Strategic Implications.” November 20, 2007. New York.

Greenlaw, David, Jan Hatzius, Anil K Kashyap, and Hyun Song Shin. 2008. "Leveraged Losses: Lessons from the Mortgage Market Meltdown." In Proceedings of the U.S. Monetary Policy Forum 2008. Chicago: Initiative on Global Markets, University of Chicago Graduate School of Business.

International Monetary Fund. 2008. "Financial Stress and Deleveraging: Macrofinancial Implications and Policy." Global Financial Stability Report. Washington (October).

Judson, Ruth, and Ann L. Owen. 1997. "Estimating Dynamic Panel Data Models: A Practical Guide for Macroeconomists." Finance and Economics Discussion Series 97-3. Washington: Board of Governors of the Federal Reserve System.

Mishkin, Frederic S. 2008. "Comments [on 'Leveraged Losses: Lessons from the Mortgage Market Meltdown']." In Proceedings of the U.S. Monetary Policy Forum 2008. Chicago: Initiative on Global Markets, University of Chicago Graduate School of Business.

Muellbauer, John. 2007. "Housing, Credit, and Consumer Expenditure." In Proceedings from the 2007 Jackson Hole Symposium. Federal Reserve Bank of Kansas City.

Standard \& Poor's. 2008. "Standard \& Poor's Revises U.S. Subprime, Prime, and Alternative-A RMBS Loss Assumptions.” New York (July 30). 
